\title{
The smuggled budgie: case study of an Australian loanblend ${ }^{1}$
}

\section{Introduction}

The Budgerigar is a small Australian parrot, known around the world as a talkative cage bird, though by other names:

\begin{abstract}
While science called these small Parrots the Splendid Grass Parakeet (Melopsittacus undulatus), the first British colonists in Australia called them 'Canary Birds' because of the chattering and chirping sound they seem to constantly be making. Over the years, they have been called the Parakeet Undulated - because of the wavy markings on their wings and Zebra Parakeets - because of the apparent black and white strip markings on their heads, and Shell Parakeets. While most commonly known today in the United States as Parakeets or shortened to just 'Keets;' in Germany they as called: Wellensittich, in France they are known as: Perruche Ondulees; in the Low Countries [the Netherlands and Belgium] they are referred to as: Grasparkieten; in Italy they are called: Parrochetto; in Spain and Portugal they are known as: Periquito, in Sweden and Denmark they are referred to as Undalat and in Finland Undulaatti. It is only in the United Kingdom and the Common Wealth nations, and to a lesser degree in the United States where the corruption of the Aboriginal term is used for their name. (von Kamrath 2006)
\end{abstract}

Of Australia's native fauna the Budgerigar is nowadays the most numerous overseas, from exports in the 1840-1850s, and "the world's most successfully marketed pet” (Olsen 2011: 18). This distinctive green bird was first noticed by European colonists in 1791 (Australian Faunal Directory 2011), but was hardly known to the incoming settlers until the 1840s, when it suddenly became popular and then versions of the name budgerigar were adopted in English. The 1840s was the peak period generally for the adoption of fauna words into Australian English from Australian Aboriginal languages. ${ }^{2}$

Quite how the word budgerigar became established in English must be inferred from the historical evidence, and it makes a chequered story. I present

\footnotetext{
1 I presented this paper to the Etymology Symposium, 17-18 April 2010, ANU Kioloa Campus and to the ALS annual meeting, 7-9 July 2010 at The University of Queensland, and I thank the participants for their comments. I am grateful to Bruce Moore and the AND Centre for discussion and access to its files, and to Michael Walsh for showing me Gardner (1854). For assistance with the Leichhardt sources I am grateful to the translator Tom Darragh, and Rod Fensham and Henry Nix.
}

2 Between 1845 and 1860, 43 fauna words were borrowed, out of the about 400 total loans (Leitner 2004: 153, Diagram 3-2 and Leitner 2007: 205, Figure 1). 
first the range of published origin accounts, to which I then add further early evidence previously unadduced, and give a fuller account. A review of previous investigation of the etymology of this one word well illustrates Trask's (1996: 353) account of the important requirements of such work, which draw on good historical sense at least as much as linguistics. I conclude with comments on the kind of borrowing of which this case study is an instance.

\section{Previous accounts of budgerigar origin}

A number of etymologies for budgerigar have been published over more than a century. Because the bird is quite distinctive, and even the layman can readily identify it, there is no uncertainty about the denotation of early (or later) records, and virtually all ${ }^{3}$ agree that the source involves Australian languages of NSW. The variation among the records is in the form of the word, and around thirty different spellings have been used. All the published etymologies draw on one or both of two established words:

(1) budgery boojery 'good', in former NSW Pidgin,

(2) gijirrigaa 'Budgerigar' in Kamilaroi (Gamilaraay)

The stated processes can be classified as either (A) or (B) separately, or jointly $(\mathrm{AB})$ :

(A) compound of (1) budgery with: gar 'cockatoo' (OED, Morris [1898] 2011)

'bird' (Chisholm 1963) 'little' (popular) or gar 'food' (Cayley 1935: 15)

(AB) alteration of (2) gijirrigaa influenced by (1) budgery (Ramson 1966, 2002;

American heritage dictionary Morris 1969)

(B) misapprehension of (2) gijirrigaa (Ramson 1964, AND, AAWE, Dixon 2009)

I show that the best etymology is most similar to (AB), but drawing on a source word like $b \mathrm{VdjRigaa}$ in one or more NSW languages.

\section{The sources}

First, we need to consider all the available evidence, which is gathered in chronological order in Table 1.

3 "As late as 1951 an American writer pronounced that the name derived from an old English word, 'budgy', meaning well-furred, or well-bearded” (Chisholm 1963: 175). 


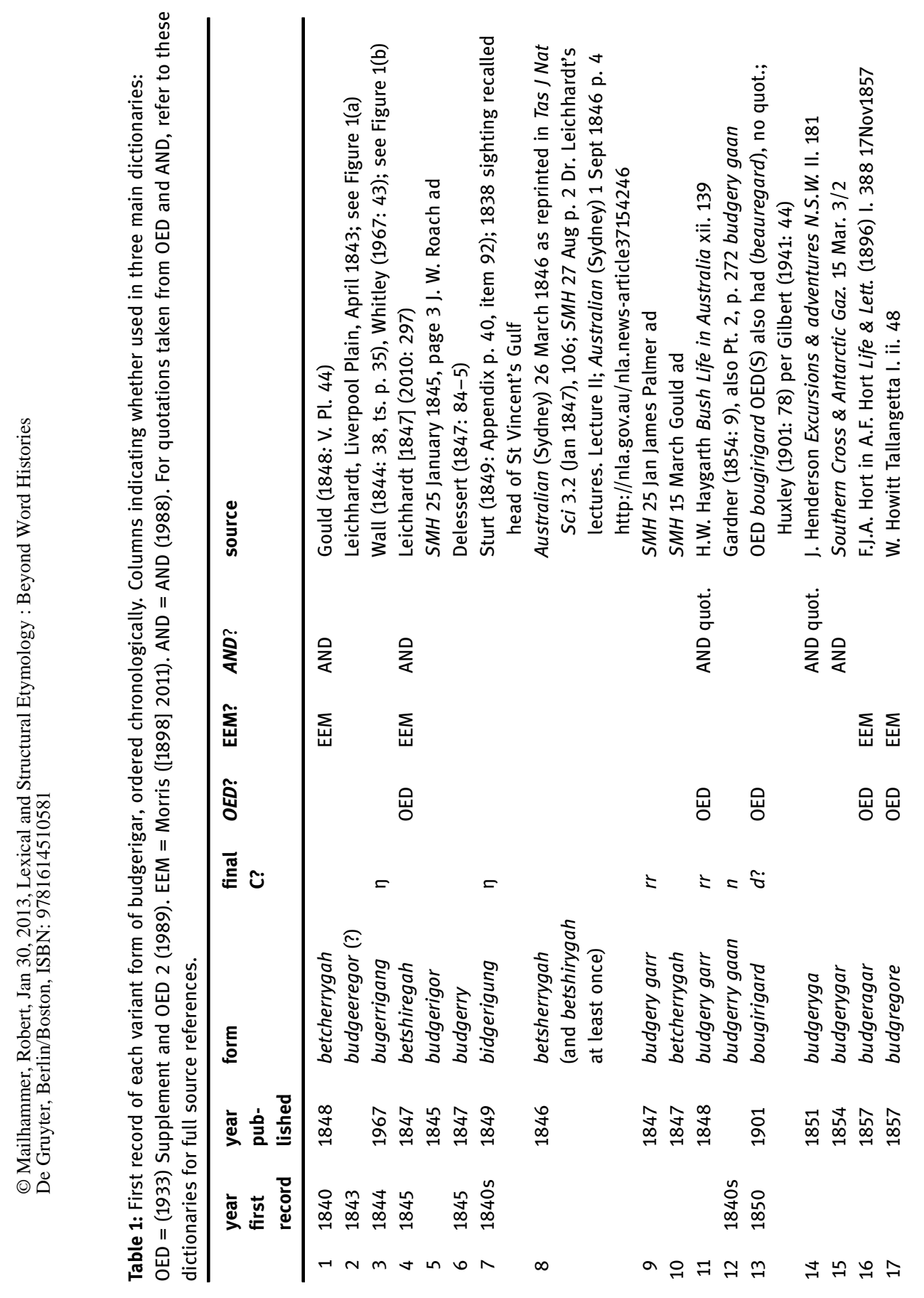




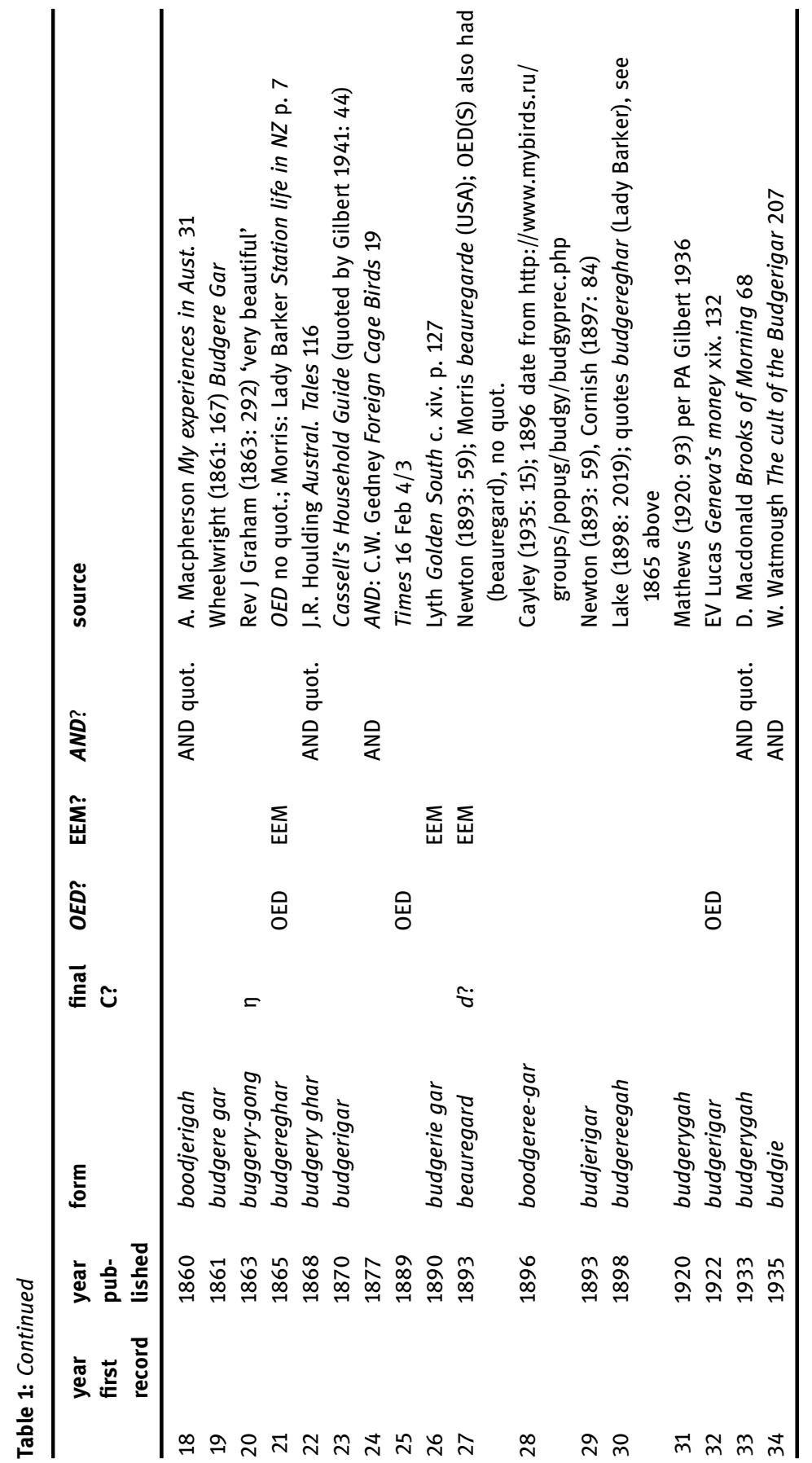


The evidence of the first decade is crucial. Note that the rows of Table 1 are ordered by the date of the record, which in some cases is years prior to the publication date. The three interior columns headed OED, EEM and AND indicate whether the particular quoted source was used in each of the three indicated dictionaries. It is striking that of the ten earliest quotations, spanning 18401847, only one was used by the OED (row 4), and only two by Morris and the AND (rows 1 and 4). Hence we need to reconsider the etymology in the light of the additional early evidence.

\section{The form of the source word}

A lot of the early records in Table 1 were written in Sydney especially in the newspaper, and are second hand and unlikely to have been heard directly from speakers of relevant Australian languages. Leaving these aside, there appear fortunately to be several independent hearings of the word most likely from Aboriginal speakers. These are collected in Table 2, and were on the Liverpool Plains by naturalists Gould and then Leichhardt (rows 1 and probably 2), probably between Goulburn and Gundagai (row 3, the Australian Museum collector W.S.

\begin{tabular}{llll} 
& year & form & source \\
\hline 1 & 1840 & betcherrygah $^{\text {budgeeregor }}{ }^{4}$ & Gould (1848: V. Pl. 44) \\
2 & 1843 & L. Leichhardt, Liverpool Plains, April \\
3 & 1844 & $\begin{array}{l}\text { bugerrigang }^{5} \\
\text { bidgerigung }\end{array}$ & Wall (1844: 38), Whitley (1967: 43) \\
7 & 1840 sturt (1849: Appendix p. 40 item 92); & 1838 sighting recalled from head of St Vincent's Gulf \\
& & budgerry gaan & Gardner (1854: 9, Pt. 2, p. 272) \\
\hline
\end{tabular}

Table 2: Records most direct from an Australian language; rows selected from Table 1.

\footnotetext{
4 Leichhardt's notebooks are in the Mitchell Library, Sydney. Darragh (p.c.) kindly provided an excerpt from his translation (2011) from the German, and guided me to the relevant passage of the manuscript (opposite page 191 in MSS 683/1). The handwriting (Figure 1(a)) is unclear, and involves a crossing out of a pair of letters, possibly gh, substituted by dgee or possibly $d g u$. Darragh (p.c.) adds "When L saw the budgerigars he was with Francis Townsend Rusden, a local squatter, who had a run on the Gwydir River."

5 Wall (1844: 38). The typescript has "Bugernigang Parrot" (p. 35). Whitely (1967: 43) says "(the writing is not clear; it could be Bugerrigang)" and my reading of Wall's manuscript (Figure 1(b)) favours Bugerrigang; and there is no other record of a medial nasal in the budgerigar word.
} 
(a)

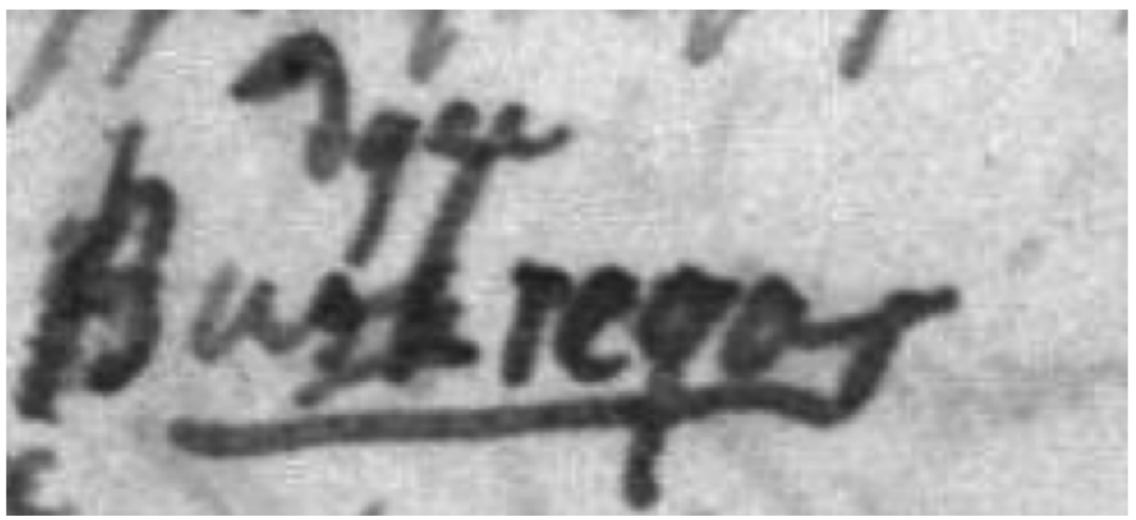

(b)

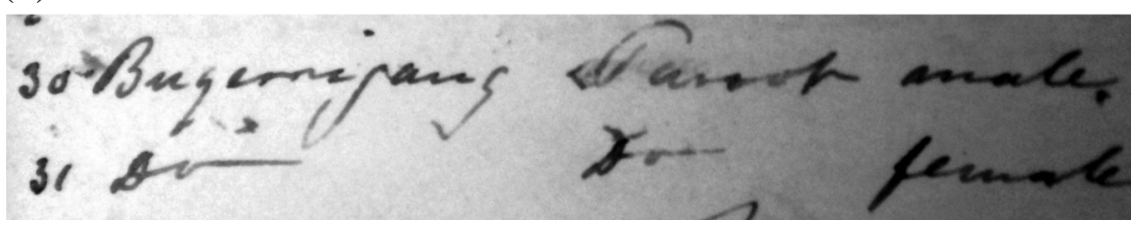

Figure 1: Oldest extant manuscript records of the budgerigar word (a) L. Leichhardt 1843, [MLMSS 639/1 opp. p. 191] State Library of NSW (b) W.S. Wall 1844, @ Australian Museum, Sydney; the second line reads ' 31 Ditto Ditto female'.

Wall on a journey south-west of Sydney), by the explorer Sturt (row 7); "Sturt does not state which natives employed his term; they may have been those of eastern New South Wales" (Cleland 1937: 41 per Gilbert 1941: 44); and by the New England tutor Gardner in the period 1842-1854 but likely by 1844 . The two oldest extant manuscript records are reproduced in Figure 1.

Gould's (row 1) exploring party was on the Liverpool Plains December 1839 and January 1840, and "consisted of five Europeans and two intelligent aborigines, Natty and Jemmy, whom Gould termed his 'faithful companions' and whose knowledge of wild life and bushcraft he found very helpful." (Hindwood 1938: 100)

Both Wall and Sturt's records are unlikely to be completely independent of Gould's. Wall worked at the Australian Museum in Sydney and would surely have heard of Gould's discoveries; and "Whilst in Sydney he [Gould] visited the explorer Charles Sturt at Varroville, near Minto, and was greatly impressed by Sturt's water-colour drawings of Australian parrots, which he desired to purchase" 
(Hindwood 1938: 97). However both Wall and Sturt used rather different spellings, and both differed from Gould in recording a final velar nasal. ${ }^{6}$

We can see in Table 2 that the word was in the 1840s known across a large part of inland NSW, and even when Anglicized had at least two forms: ['bVtfəriga:] at the Liverpool Plains (about $300 \mathrm{~km}$ north of Sydney), possibly ['bVtfəxiga:n] in the state's north, and ['bVdzəxigan] southwest of Sydney. ${ }^{7}$ The records involving the final nasal fit with the longer form being Wiradjuri, which, unlike its northern neighbours, tolerates word-final $\eta$ (and $\eta$ ). The two versions of the word, with and without the final nasal consonant, fits a known sound correspondence in central NSW languages. ${ }^{8}$

There is just one other later record which shows a final nasal: buggery-gong (row 20), of indeterminate location, in a poem apparently written in Ireland on the basis of the author's returned eldest brother's tales of over twenty years in Australia, particularly in southern NSW (Graham 1880: 86-87).

For completeness, possible evidence from placenames can be mentioned. (a) Bedgerabong on the Lachlan River in central NSW is likely to be the placename listed as 'Budgery bong shell parrot' by the clerk Beaver (1899) at nearby Wyalong. There are two relevant Ngiyampaa and Wiradjuri suffixes: -ba:N (Donaldson 1980: 118-119) and -gaN (mentioned in section 6 below). (b) Two other placenames of unknown origin have a potentially corresponding form: Mount Bootheragandra near the lower Lachlan (likely involving the Wiradjuri Comitative suffix, here spelled -dra) and Badjerrigarn parish north of Broken Hill.

The version ending in the velar nasal is corroborated by what is presumably a cognate word in Wemba Wemba, a language of the Murray River: widjorigon 'budgerigar', as recorded in the 1960s by Hercus (1986: 195). If this word proves to be cognate (with $w$ - corresponding to widespread $b$-) then it provides additional plausibility, if it is needed, for the word encountered on the Liverpool Plains having an initial bilabial rather than velar stop. The reconstitution of the original forms in the languages of inland NSW has of course to be in terms of

6 Sturt's manuscript is probably unavailable, as is Gould's: “Whatever journals Gould kept when he was in Australia seem to have been lost or destroyed" (Hindwood 1938: 112).

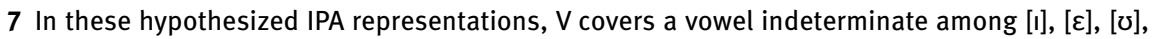
[e] or [a] including the ambiguity of $\langle\mathrm{u}>$ in English spelling. Also note that the English [ג] would match both the retroflex glide $[\Lambda]$ and apical tap/trill [r] which contrast in the Aboriginal languages; and given the spellings a further possibility is that the original word ended in the flap or trill $[r]$.

8 Donaldson (2002: 164, 178). Austin (1997: 24-25) shows how "word-final *ng in PCNSW [Proto Central NSW] descends as zero in PGY [Proto Gamilaraay-Yuwaaliyaay] and as $N$ in PWW [Proto Wayilwan-Wangaaybuwan]." An example is *burralgang 'brolga' reflected as Gamilaraay burralga, Wiradjuri burralgang 'brolga, Grus rubicunda'. 
the (quite similar) phonologies of those languages (Austin 1997). The Wemba Wemba form does also point to the reconstituted first vowel being /i/ not $/ \mathrm{u} /$, and thus in this respect matching the vowel recorded by Gould (row 1) and Sturt (row 7) and distinct from the first vowel of NSW Pidgin budgery boojery 'good'.

\section{Propagation and reanalysis of the word as NSW Pidgin}

John Gould, the "father of Australian ornithology", conveys how the Budgerigar came to the sudden attention of the European population of NSW:

For instance the beautiful little warbling Grass Parrakeet (Melopsittacus undulatus), which prior to 1838 was so rare in the southern parts of Australia that only a single example had been sent to Europe, arrived in that year ${ }^{9}$ in such countless multitudes on the Liverpool Plains, that I could have procured any number of specimens, and more than once their delicate bodies formed an excellent article of food for myself and party. (Gould 1865: 5)

There is the suggestion that the bird was a novelty also to the Aboriginal population:

Gould understood that the birds might be eruptive, prone to 'periodic exodus', writing in 1866 to egg-collector Edward Ramsay, future Curator of the Australian Museum: 'The Black Fellows of the Upper Hunter told me that the little Melopsittacus undulatus had come to meet me, for they had never seen the bird in that district until the year I arrived'. (Olsen 2011: 18-19; also quoted by Hindwood 1938: 107-108)

This fits with the naturalist Leichhardt's later supposition in north Queensland:

the Betshiregah (Melopsittacus undulatus, Gould.) were very numerous, and it is probable that the plains round the gulf are their principal home, whence they migrate to the southward. (20 June 1845 entry, Leichhardt [1847] 2010: Chapter 9)

It is also relevant that the European settlement was at that time just beginning to spread into the plains west of the Great Dividing Range; possibly this spread was also widening the budgerigar's range, for reasons similar to those that applied to the galah (a larger parrot) and crested pigeon, as argued in detail by Gammage (2009).

9 Gould first arrived in NSW in February 1839. His party explored the Liverpool Plains in December 1839 and January 1940 (Hindwood 1938: 97-98, 100). 
The first record of the word, Gould's betcherrygah, was apparently adopted in modified form as betsherrygah by Leichhardt ${ }^{10}$ or at least the newspapers reporting his popular 1846 public lectures (row 8), even though Leichhardt had earlier himself written the word quite differently (row 2). Gould's collector naturally used Gould's spelling in newspaper advertisements in 1847 (row 10).

The other set of spellings, representing the second consonant as $d g$ rather than $t c h$ or $t s h$, had already appeared in the newspapers. The first published occurrence of the word in any form (as budgerigor, row 5) was in 1845 in weekly advertisements by J. W. Roach (the John Roach who had preceded W. S. Wall as collector for the Australian Museum, Iredale and Whitley 1962, 1968; Whitely 1967: 42) soliciting live birds for his Repository in Hunter St, Sydney, and the next published occurrence is by a Frenchman impressed by his visit to Roach's shop the same year (row 6).

\begin{abstract}
Mais le perroquet le plus mignon, le plus rare, et par conséquent un des plus chers, est celui appelé budgerry. Il est de la grosseur d'un petit serin, de couleur vert-feuille clair, et zebré de noir sur le dos. Rien n'est plus amusant que de l'entendre jaser et demander un morceau de pain. (Delessert 1847: 84-5)
\end{abstract}

[But the cutest, rarest parrot, and therefore one of the most expensive, is called budgerry. It is about the size of a little canary, light leaf-green in colour and zebra-striped black on the back. Nothing is more amusing than to hear it chatter and ask for a piece of bread.]

This shows that budgerry was by 1845 a way of referring to this parrot. As written in a French context, the first vowel was probably a representation of [ $\mho]$ rather than a low vowel [a]. Delessert implies the name was appropriate to the parrot's beauty, rarity and high price, and it seems likely he was alluding to the word budgery boojery 'good' (AND) as budgery (with first vowel high and back) was one of the most common words in the NSW Pidgin of the era. ${ }^{11}$ The Sydney area and the central coast of NSW is the one part of the continent where the Budgerigar is generally absent (Australian Faunal Directory maps), and so the Sydney Language would have lacked a word for the parrot. Then from the mid1840s the commercial trade and the export of budgerigars as cage-birds took off, and so the bird became well-known in Sydney too. ${ }^{12}$ As Wafer and Lissarrague

10 Leichhardt cites the scientific name complete with attribution to Gould, and "Leichhardt had a respect for Gould's ornithology" (Henry Nix, p.c.).

11 The word was taken from the Sydney Language (AND, budjari, Wafer \& Lissarrague 2008: 814).

12 "Meanwhile, by 1859, with the birds so successfully being bred in Europe that the export market in Australia collapsed where Budgerigars had previously been selling for 10 silver Shillings a piece" (von Kamrath 2005: 6). 
(2008: 405) summarize, "It is also noteworthy that NSW Pidgin was the vehicle by which many words from NSW Aboriginal languages entered Australian English”; sufficient numbers of the English-speaking settlers were familiar with some of the common words of the NSW Pidgin, which had emerged decades before, that it was reasonable when they encountered the inland words ['bVtforiga:] and ['bVdzəxigan] for them to match the first three syllables of the parrot's indigenous name with budgery boojery 'good'. That this was a continuing pronunciation of the parrot's name is also evidenced by the noted naturalist T. H. Huxley's (row 13) use $\mathrm{e}^{13}$ of the spelling bougirigard (with unambiguous high back first vowel). And the meaning component is evident in Grahams' buggerygong (row 20) which is explicitly glossed as 'very beautiful'. ${ }^{4}$

When the first three syllables of budgerigar was given the status of a morpheme, the remainder of the word would have been taken to be a second morpheme, and so gar would naturally have been taken to mean something like 'parrot'. This combination is suggested by the version Budgery Garr first attested in James Palmer's newspaper advertisements (row 9). It finds support in the word in the language of NSW north coast (kaar 'white cockatoo' Curr 1886 vocabulary 184 [The Clarence River]; kehr 'white cockatoo', Sharpe 1998: 111), though I lack evidence as to whether this was adopted into NSW Pidgin. There is however the similar word gang-gang which had been borrowed into English, probably from Wiradjuri (AND), as the common name of another larger parrot.

Thus, even with the benefit of additional early evidence, we are led to agree with elements of the first published etymology (Morris [1898] 2011). Morris suggested the relation to bŭdgeri or boodgeri 'good, excellent' in "the Port Jackson dialect”, the Sydney Language, ${ }^{15}$ and observed that in NSW

gar is common as first syllable of the name for the white cockatoo, as garaweh. See Galah. In the north of New South Wales kaar = white cockatoo.

13 "As Huxley was in the vicinity of Sydney for several years, it is reasonable to assume that Bougirigard was the popular name about 1850" (Gilbert 1941: 44).

14 In the same volume buggery buggerie 'good' occurs in two representations of NSW Pidgin: "You saucy debil, what for nimbly when Mine make it buggery wool jump up" Graham (1863: 208) and "You piala buggerie along mine brother belonging to Bobdindi" Graham (1863: 219). The reminiscences are based on the editor's elder brother's stay in NSW c1834-1854 (Graham 1880: 86).

15 Dixon (2008: 139) styled this suggestion as "gratuitous", and used it as the sole illustration of his claim that "[w]hen Morris ventured beyond listing quotations, quite often fantasy took over". Dixon apparently did not consider seriously the mediating role of NSW Pidgin. 
While Morris' suggestions about gar in cockatoo names may well be an invalid analysis of the relevant Aboriginal language words, they may be valid for folk etymology at the time English speakers with some awareness of NSW Pidgin were assimilating the word as budgerigar.

\section{Gamilaraay origin}

The study of the budgerigar etymology has had to confront a puzzle that the word has a somewhat different form recorded in Gamilaraay (Kamilaroi), the language of the Liverpool Plains where explorers first encountered the word. The first published wordlists of Gamilaraay date from over four decades after Gould's first record; and the two substantial wordlists both contain a word for the budgerigar:

- gījorigā 'parrot (small green)' (Ridley 1875: 22)

- gidgerreegah 'small green parrot' (Parker 1905: 145),

and this is corroborated in the modern dictionary of Gamilaraay (Ash, Lissarrague and Giacon 2003: 86):

- gidjirrigaa '1. budgerigar 2. star (a particular star) A yellowish star in the north, opposite the Southern Cross: possibly Arcturus'

- gidjirr '1. gidgee, Large wattle tree ... 2. yellow ochre 3. yellow' gidjirrgidjirr 'yellow. From gidjirr (gidgee tree) because of its yellow flowers'16

The -gaa element however is not explained. It may be the same ending as in the name Mullyangah 'ancestral eagle hero; morning star' (Parker 1896, sc. Maliyangaa, cf. maliyan 'eagle', Ash, Lissarrague and Giacon 2003: 106), and may correspond with a Wiradjuri and Ngiyampaa suffix -gaN (Hale 1846: 502, Donaldson 1980: 105-6).

The puzzle is why these wordlists should lack the version of the word beginning with the bilabial stop [b]. This could be related to another puzzle, as to how the Aborigines of the Liverpool Plains supplied Gould with a term for the bird which they told him was new to them too (1866 quotation in previous section). One can speculate that in 1839 the Gamilaraay who Gould met somehow applied

16 Compare, in the languages on the south and west: Wiradjuri Gidgerragar 'Budgerragar parrot' (Tibbetts 1900: 62); Ngiyampaa kityirrikaa 'budgerigar' ( kityirrikaaN- before certain consonant-initial suffixes and where $\mathrm{N}$ is an assimilating nasal, Donaldson 1997: 67); and gidjiri 'bird: robin red-breast' in the Paakantyi language of the lower Darling River (Hercus 1982: 286) where the $r$ is an alveolar flap. 
a form something like $b$ VdjiRigaa, but by 1875 the speakers had modified this to gidjirrigaa by folk etymology within Gamilaraay, partly in reaction to budgerigar versions having been taken up by English speakers. One difficulty in investigating this further is that the budgerigar word can be expected to have spread with English speakers on the colonial frontier, which could be a source of subsequent records of a budgerigar-like word in other Aboriginal languages.

Also in the above two early Gamilaraay wordlists there is a discrepancy in the colour. In the wild the budgerigar is predominantly green, as in the glosses, and also in the early descriptions; ${ }^{17}$ predominantly yellow individuals (and later other colours) arose from captive breeding. ${ }^{18}$ Gamilaraay has the contrasting colour term "gawarrawarr green. Also recorded as 'blue'." (Ash, Lissarrague and Giacon 2003: 82).

In any case, English speakers who had already learned the form of the budgery garr type could be expected to keep to the version beginning with [b] even if they encountered casually the gidjirrigaa form. Note however that there was no suggestion in newspapers or elsewhere during the decades of popularity that the $b$-initial form was in error or at variance with Aboriginal speech.

My scenario is at variance with the view that there was a misapprehension of gijirrigaa (Ramson 1964, AND, AAWE, Dixon 2009), in that I take the earliest recorders to have accurately noted an initial bilabial (not velar) stop. The more nuanced view that there was an alteration of gidjirrigaa influenced by budgery (Ramson 1966, 2002; Morris 1969) is closer to my scenario, but I still differ in that I accept as original in the language of the Liverpool Plains (let us say Gamilaraay) a word with an initial bilabial stop, something like bVdjiRigaa, and I postulate the gidjirrigaa variant could be a later 19th century construct (by Gamilaraay people effectively creating a loanblend from NSW English budgerigar).

17 The first two specimens to arrive in Europe $(c 1800,1831)$ were described as green (von Kamrath 2005: 1-2); and see John Gould (1848)'s famous illustration, Plate 44 in volume 5, available at http://australianmuseum.net.au/image/Budgerigar-aka-Warbling-Grass-Parrot/ and widely reproduced as in Olsen (2011: 18); and Leichhardt's description in his April 1843 notebook "Brow yellow, back side of the neck, shoulders, the round feathers with yellow and black transverse stripes, rump green, the two middle tail feathers the longest, blue. Underside of them black, the lateral whitish and yellowish. Anal region, belly and breast and under the wing joint green, under wing grey, throat yellow with isolated black patches" (translated from German by Darragh 2011).

18 Cayley (1935); "It was also in 1870s, that the first of the color mutations appeared" (von Kamrath 2005: 6); “Around 1870, a yellow budgie became available, developed from a natural but extremely rare variant” (Olsen 2011: 20). 


\title{
7 Later developments
}

At some stage, before living memory, the English pronunciation of the first vowel of budgerigar settled to the modern low vowel. Unfortunately Morris ([1898] 2011) and other late 19th century writers are not explicit about this detail. The predominance of the low vowel pronunciation is likely to have come from spelling pronunciation, that is, the influence of English orthography, bringing the word into line with established words such as budge, drudgery. The same change has applied in the history of the word gunyah 'makeshift shelter', also from NSW Pidgin and originally pronounced with high back vowel (compare the cognate loans goondie gundy, AND).

The vowel must have settled on the low value well before 1935, by which time the word had in Australia undergone the usual truncation to budgie (row 34).

Writing in England, Gedney (1877) was one of the first to publish what has become the standard spelling of budgerigar, and noted

Lately it has become the fashion to call these birds budgerigars. (quoted in Olsen 2011: 20) ${ }^{19}$

\section{The loanblend}

The way that budgerigar formed in modern Australian English from one or more Aboriginal languages of NSW is an instance of the Law of Hobson-Jobson, named $(O E D)$ by Morris ([1898] 2011: xv):

\begin{abstract}
When a word comes from a foreign language, those who use it, not understanding it properly, give a twist to the word or to some part of it, from the hospitable desire to make the word at home in its new quarters, no regard, however, being paid to the sense. The most familiar instance in English is crayfish from the French écrevisse, though it is well known that a crayfish is not a fish at all.
\end{abstract}

Morris overstated the lack of regard to sense. In his example, a crayfish significantly has in common with fish that it is an edible aquatic animal. In the case of budgerigar, the parrot has long been regarded as 'good', indeed the ideal

19 “It was Britain's King George V, who secured the name of the bird known among fanciers in the United Kingdom, the Common Wealth [sic], and the United States as Budgerigars, when in 1930, he agreed to become the patron of the Budgerigar Club, which had been founded in 1925 , but requested the name of the club be changed to the Budgerigar Society" (von Kamrath 2006). 
cage-bird, and a distinctive bird which would be expected to have an 'Aboriginal name', and so in the context of mid-19th-century NSW it would have been easy to match it with the NSW Pidgin budgery 'good'. Generally speakers when learning the novel word strive to make some, if incomplete, sense of the attribution they are adopting.

For a general account of lexical borrowing there is no need to go past Haugen's classic paper, which (alongside loanword) introduced the useful terminology of loanblend and loanshift (1950: 215), all defined in terms of importation and substitution, whether phonemic, morphemic or semantic.

This distinction between importation and substitution [emphasis in original] applies not only to a given loan as a whole but to its constituent patterns as well. (Haugen 1950: 212)

The analysis proposed here of the borrowing of budgerigar could be seen as having two stages: first a loanblend formed in the mediating NSW Pidgin, and from there a normal loanword into Australian English. The stage of budgery garr etc. would be a loanblend, in that the budgery of NSW Pidgin was substituted for the first three syllables of the original four-syllable word ${ }^{20}$ (and perhaps for some speakers also the last syllable was also substituted by a word like gar 'parrot' from other NSW languages). This staged hypothesis falters however insofar as the mediating NSW Pidgin was not the native language of anyone. We should instead presume that it was speakers of English who formed the budgery garr (literally 'beautiful parrot') loanblend in NSW Pidgin (perhaps even taking it to be faithful to the original language), and simultaneously adopted the combination into their own English.

Because of the imputed simultaneity I have not cast the budgery garr as an instance of folk etymology. In this I follow Mailhammer's (2008: 179-180) useful distinction:

although the formal mechanisms of folk etymology and phonetic calquing are very similar, there are good theoretical reasons to keep the two processes separate ... The main argument is that folk etymology refers to a diachronic reanalysis of an already existing item that is no longer understood, whereas phonetic calquing refers to a synchronic process, whose aim is to integrate foreign material that is not immediately understood.

20 The substitution with budgery falls under Zuckermann's (2004) definitions of phonosemantic matching (PSM) and multisourced neologization (also phonetic calquing) and thus under the wider term camouflaged borrowing (also folk-etymological nativization). Zuckermann claims that "Traditional classifications of borrowing ignore it [PSM] altogether, and categorize borrowing into either substitution or importation. However, as this paper demonstrates, PSM is a distinct phenomenon, which operates through simultaneous substitution and importation." Haugen's (1950: 215) definition stated that "loanblends show morphemic substitution as well as importation" and so I find Haugen's earlier terminology suffices to categorize the borrowing considered here. 


\section{Methodology}

In the study of the origins of English loans from Australian languages, the linguists' method has typically been to scan the primary linguistic sources, focusing on early wordlists (usually published, some in the form of unpublished manuscripts). Linguists have typically not had the resources, or the historical training, which would lead them to consider all other early occurrences, which are usually incidental in some other context than language description.

Previous etymologists (after Morris) had overlooked the relevant work of ornithologists Cleland (1937), Gilbert (1941), Iredale and Whitley (1962, 1968), and Whitley (1967). Gardner (1854) and Graham (1863) were not in the AND select bibliography. Admittedly the early newspaper evidence has become much more accessible only in the last decade thanks to the digitization programme at the National Library of Australia.

The trail behind budgerigar illustrates in particular "the importance of locating and consulting all available documentation" (Trask 1996: 353); and "the importance of providing a plausible pathway by which the name could have got to where it is attested by the time it is attested". The proposed pathway (or pathways) need to be tested against the "three feasibilities" identified by Ramson (2002: 17-26): chronological, geographical, and logical. Ramson's discussion of "logical feasibility" concerns sense development (including in compounds), but could extend to embrace change and adaptation of word form (morphological and phonological).

\section{Conclusion}

The inferred etymology of Australian English budgerigar (as a loanblend formed in NSW Pidgin), and the range of previous accounts of it, illustrate some of the pitfalls of the investigation of loan words. The imputed loan pathway involves popular projection onto scarcely-known source languages, mediated by the intercultural pidgin of the era.

When tackling the etymology of a loanword, one needs to hypothesize a path of adoption with particular circumstances of history and sociolinguistics. Attention needs to be paid to how solid the early sources are, the circumstances of interlanguage contact, and the paths of popularization. Multiple simultaneous sources can be involved in borrowing, combined as summarized by the terms loanblend and loanshift. 


\section{References}

AAWE = Dixon, R.M.W., W.S. Ramson \& Mandy Thomas. 1990. Australian Aboriginal words in English, their origin and meaning. 1st ed. Melbourne: Oxford University Press.

AAWE = Dixon, R.M.W., W.S. Ramson \& Mandy Thomas. 2006. Australian Aboriginal words in English, their origin and meaning, 2nd ed. Melbourne: Oxford University Press.

AND = Ramson, W.S. 1988. The Australian national dictionary, a dictionary of Australianisms on historical principles. Melbourne: Oxford University Press. http://australiannationaldictionary. com.au/ (accessed 1 June 2012).

Ash, Ann, Amanda Lissarrague \& John Giacon. 2003. Gamilaraay, Yuwaalaraay \& Yuwaalayaay dictionary. Alice Springs, N.T.: IAD Press.

Austin, Peter. 1997. Proto central New South Wales phonology. In: Darrell Tryon \& Michael Walsh (eds.), Boundary rider: essays in honour of Geoffrey O'Grady (Pacific Linguistics C-136), 21-49. Canberra: Pacific Linguistics.

Australian Faunal Directory. Australian Biological Resources Study. Department of Sustainability, Environment, Water, Population and Communities. Australian Government. Species Melopsittacus undulatus (Shaw, 1805). http://www.environment.gov.au/biodiversity/ abrs/online-resources/fauna/afd/taxa/Melopsittacus_undulatus (accessed 26 August 2011).

Beaver, S.E. 1899. RASA questionnaire; accompanying letter, dated 26 Oct 1899. Wyalong, N.S.W. PDF pages 397-8 in 'anthropological society of aus roll 1', PDF file, CD-ROM 'Royal Anthropological Society of Australia manuscripts dated 1900', 2004. Geographic Names Board of NSW.

Cayley, Neville W. 1935. Budgerigars in bush and aviary. 2nd ed. Sydney: Angus \& Robertson.

Chisholm, A.H. 1963. Budgerigar. In Bird to conscription, The Australian encyclopaedia, Vol. 2, 175-6. Sydney: Grolier Society of Australia.

Cleland J.B. 1937. The history of ornithology in South Australia, Part III. Emu 37 (1). 33-47. http://dx.doi.org/10.1071/MU937033 (accessed 31 May 2012).

Cornish, C.J. 1897. Animals at work and play: their activities and emotions. London: Seeley \& Co. http://archive.org/details/animalsatworkpla00cornrich (accessed 31 May 2012).

Curr, E.M. 1886. The Australian Race, Vol. 1. Melbourne: Government Printer.

Darragh, Thomas A. 2011. Translation of Ludwig Leichhardt's Australian diary No. 2. 28 December 1842-24 July 1843. Mitchell Library MSS 683/1, item 1. (to appear in Memoirs of the Queensland Museum - Culture 8).

Delessert, Eugène. 1847. Souvenirs d'un voyage à Sydney (Nouvelle-Hollande): fait pendant l'année 1845. Paris: A. Franck.

Dixon, R.M.W. 2008. Australian Aboriginal words in dictionaries: a history. International Journal of Lexicography 21 (2). 129-152. (Revised version published in Alexandra Y. Aikhenvald \& R.M.W. Dixon (eds.), Language at large: Essays on syntax and semantics (Empirical Approaches to Linguistic Theory), 529-553. Leiden: Brill Academic Publishing, 2011).

Donaldson, Tamsin. 1980. Ngiyambaa, the language of the Wangaaybuwan (Cambridge Studies in Linguistics 29). Cambridge: Cambridge University Press.

Donaldson, Tamsin. 1997. Ngiyampaa wordworld 1: thipingku yuwi, maka ngiya, names of birds \& other words. Canberra: Australian Institute of Aboriginal and Torres Strait Islander Studies. 
Donaldson, Tamsin. 2002. The language of the Peak Hill Aboriginal people: a linguistic report in a native title claim. In: John Henderson \& David Nash (eds) Language in native title, 161185. Canberra: Aboriginal Studies Press.

Gammage, Bill. 2009. Galahs. Australian Historical Studies 40(3). 275-293.

Gardner, William. 1854. Production and resources of the Northern and Western districts of New South Wales, 1842-1854. Volume 1. Mitchell Library, Sydney. MS A176-1, microfilm CY 89.

Gedney, C.W. 1877. Foreign cage birds: containing full directions for successfully breeding, rearing, and managing the various beautiful aviary birds imported into this country. London: 'The Bazaar' Office.

Gilbert, P.A. 1941. The vernaculars of Melopsittacus undulatus, Shaw. Proceedings of the Royal Zoological Society of NSW 1940-41. 44-45.

Gould, John. 1848. The birds of Australia. 7 vols. London: John Gould.

Gould, John. 1865. Handbook to The birds of Australia. London: Google Books http://books. google.com/books?id=LUcDAAAAQAAJ (accessed 1 June 2012).

Graham, Rev. John (ed.). 1863. Lawrence Struilby: or, Observations and experiences during twenty-five years of bush-life in Australia. Appendix by the Rev. John Graham 'Nightthoughts in the Australian bush' [poem], pp. 291-292. London: Longman, Green. Google Books http://books.google.com.au/books?id=NcQNAAAAQAA) (accessed 1 June 2012).

Graham, Charles. 1880. Memoir of the Rev. John Graham. London: J.F. Shaw. http://openlibrary. org/works/OL7899333W/Memoir_of_the_Rev._John_Graham (accessed 31 August 2011).

Hale, Horatio. 1846. The languages of Australia [including 'Wiradurei'], pp. 479-531 in Ethnology and Philology, Volume 1, in Narrative of the U.S. Exploring Expedition during the years 1838, 1839, 1840, 1841, 1842, under the command of Charles Wilkes, U.S.N. Philadelphia: C. Sherman. http://www.newcastle.edu.au/Resources/Divisions/Academic/Library/Cultural \%20Collections/pdf/hale1846b.pdf (accessed 31 May 2012).

Haugen, Einar. 1950. The analysis of linguistic borrowing. Language 26 (2). 210-231.

Hercus, Luise A. 1982. The Bāgandji language. (Pacific Linguistics B-67). Canberra: Pacific Linguistics.

Hercus, Luise A. 1986. Victorian languages: a late survey (Pacific Linguistics. B-77). Canberra: Pacific Linguistics.

Hindwood, K.A. 1938. John Gould in Australia. Emu 38: 95-118. http://www.publish.csiro.au/? act=view_file\&file_id=MU938095.pdf (accessed 3 September 2011).

Huxley, Leonard. 1901. Life and letters of Thomas Henry Huxley. Vol. 1. New York: D. Appleton. http://aleph0.clarku.edu/huxley/letters/50.html (accessed 28 August 2011).

Iredale, T. \& G.P. Whitley. 1962. John Roach and the Budgerigar. Australian Natural History 14(3). 99-102.

Iredale, T. and G.P. Whitley. 1968. John Roach, the Budgerigar, and the unfortunate officer. Proceedings of the Royal Zoological Society of NSW 89: 36-39.

Lake, Joshua (ed.). 1898. A dictionary of Australasian words, in The Australasian supplement to Webster's international dictionary. Springfield, Mass.: G. \& C. Merriam Co.

Leichhardt, Ludwig. 2010. [1847] Journal of an overland expedition in Australia, from Moreton Bay to Port Essington, a distance of upwards of 3000 miles, during the years 1844-1845. Adelaide: eBooks@Adelaide. http://ebooks.adelaide.edu.au/l/leichhardt/ludwig/l52j/ (accessed 28 August 2011).

Leitner, Gerhard. 2004. Australia's many voices. Australian English - The national language (Contributions to the Sociology of Language). Berlin \& New York: Mouton de Gruyter. 
Leitner, Gerhard. 2007. The Aboriginal contribution to Australia's language habitat. In: Gerhard Leitner and lan G. Malcolm (eds.), The habitat of Australia's Aboriginal languages: past, present, and future, 197-236. Berlin \& New York: Mouton de Gruyter.

Mailhammer, Robert. 2008. The wolf in sheep's clothing: Camouflaged borrowing in Modern German. Folia linguistica 42 (1). 177-193.

Mathews, Gregory M. 1920. The birds of Australia. - Supplement 1, check list of the birds of Australia. London: Witherby.

Morris, Edward Ellis. 2011. [1898] Austral English: A dictionary of Australasian words, phrases and usages. Cambridge: Cambridge University Press. http://books.google.com/books? $\mathrm{id}=5$ UkgUWydJmIC (accessed 30 May 2012).

Morris, William (ed.). 1969. The American Heritage dictionary of the English language (International ed). [New York]: American Heritage Pub. Co.

Nash, David. 2009. Australian Aboriginal words in dictionaries: a reaction. International Journal of Lexicography 22 (2). 179-188.

Newton, Alfred. 1893. A dictionary of birds. London: A. and C. Black. http://archive.org/details/ dictionaryofbird00newt (accessed 31 May 2012)

$O E D=$ Oxford English Dictionary. 1933. Supplement. Oxford. Oxford University Press.

$O E D=$ Oxford English Dictionary. 1989. 2nd ed. online. Oxford. Oxford University Press.

Olsen, Penny. 2011. The flight of the Budgerigar. The National Library Magazine (June 2011). 18-21. http://www.nla.gov.au/pub/nlanews/2011/jun11/the-flight-of-the-gudgerigar.pdf (accessed 9 May 2011).

Parker, K. Langloh. 1896. Australian Legendary Tales: Folklore of the Noongahburrahs as told to the Piccaninnies. Melbourne: D. Nutt; London: Melville, Mullen \& Slade. http://www. gutenberg.org/ebooks/3833 (accessed 3 June 2012).

Parker, K. Langloh. 1905. The Euahlayi tribe: a study of Aboriginal life in Australia. London: A. Constable.

Ramson, W.S. 1964. Aboriginal words in early Australian English. Southerly: the magazine of the Australian English Association 24. 50-60.

Ramson, W.S. 1966. Australian English: an historical study of the vocabulary, 1788-1898. Canberra: Australian National University Press.

Ramson, W.S. 2002. Lexical images: The story of the Australian National Dictionary. Oxford: Oxford University Press.

Ridley, William. 1875. Kamilaroi, and other Australian languages. Sydney: Thomas Richards, Govt. Printer.

Sharpe, Margaret C. 1998. Dictionary of Yugambeh including neighbouring dialects (Pacific Linguistics C-139). Canberra: Pacific Linguistics.

$\mathrm{SMH}=$ Sydney Morning Herald. Sydney: Fairfax Media.

Sturt, Charles. 1849. Narrative of an expedition into central Australia, performed under the authority of Her Majesty's Government, during the years 1844, 5, and 6. Vol. II. London: T. and W. Boone. http://books.google.com.au/books/pdf/Narrative_of_an_Expedition_ Into_Central_.pdf (accessed June 2008).

Tibbetts, W.C. 1900. Aboriginal names in the Wooratherie Dialect, Macquarie and Castlereagh Rivers, N.S.W. Science of Man 3 (4). 62-64.

Trask, R.L. 1996. Historical linguistics. London \& New York: Arnold.

von Kamrath, G.W. 2005. The European discovery and development of the Budgerigar Part I: The men who introduced the Budgerigar to the world. http://www.archive.org/download/ tarihk6/BudgieHistoryPartlByGwVonKamarth.pdf (accessed 15 April 2010). 
http://68.7.30.3:8080/budgieclub/articles.zip (accessed 3 September 2011). (Originally published in A Bit of Budgie Chatter, December 2005. Newsletter of the Budgie Fanciers of San Diego County. http://bfsdc.com).

von Kamrath, G.W. 2006. How did the Budgerigar get its name? http://68.7.30.3:8080/ budgieclub/articles.zip (accessed 3 September 2011). Originally published in A Bit of Budgie Chatter, March 2006 (newsletter of the Budgie Fanciers of San Diego County, http://bfsdc.com).

Wafer, James \& Amanda Lissarrague. 2008. A handbook of Aboriginal languages of New South Wales and the Australian Capital Territory. Nambucca Heads: Muurrbay Aboriginal Language and Culture Co-operative.

Wall, William S. 1844. Notes of a Journey from Sydney to the Murrimbigi River in Pursuite of Specimens of Natural History. Journal Manuscript, Australian Museum Archives series AMS 265, Sydney. Typescript copy. Canberra: Basser Library, Australian Academy of Science.

Wheelwright, Horace William. 1861. Bush wanderings of a naturalist: or, notes on the field sports and fauna of Australia Felix, by an old bushman. London: Routledge, Warne \& Routledge. http://www.scribd.com/doc/78641055/Bush-Wanderings-of-a-NaturalistWheelwright-Horace-William (accessed 1 June 2012).

Whitley, G.P. 1967. William Sheridan Wall and the Australian Museum. Proceedings of the Royal Zoological Society of NSW 1965-66. 42-44.

Zuckermann, Ghil'ad. 2004. Cultural hybridity: Multisourced neologization in 'reinvented' languages and in languages with 'phono-logographic' script. Languages in Contrast 4 (2): 281-318. http://dx.doi.org/10.1075/lic.4.2.06zuc (accessed 31 May 2012). 